\title{
The Role of Innovative Work Behavior Mediates Organizational Culture on Employee's Performance
}

\author{
I MADE ASTRAMA \\ Udayana University, Denpasar, Bali, INDONESIA \\ NI NYOMAN KERTI YASA \\ Udayana University, Denpasar, Bali, INDONESIA \\ GEDE ADNYANA SUDIBIA \\ Udayana University, Denpasar, Bali, INDONESIA \\ DESAK KETUT SINTA ASIH \\ Udayana University, Denpasar, Bali, INDONESIA
}

\begin{abstract}
The aims of this study were to explain: (1) the influence of organizational culture on innovative work behavior; (2) the influence of organizational culture and innovative work behavior on employee performance; and (3) the role of innovative work behavior in mediating the influence of organizational culture towards employee performance in the Rural Bank industry in Badung Regency, Bali Province. This research was conducted in 52 Rural Bank in Badung Regency, with 156 employees as respondents. Data was collected by questionnaire instruments that had been tested for validity and reliability. Data analysis was performed using the SEM-PLS approach. The results revealed that organizational culture had a positive and significant influence on innovative work behavior. Organization culture and innovative work behavior also showed positive and significant impact on employee performance in the Rural Bank industry. In addition, it could be concluded that innovative work behavior mediates significantly the influence of organizational culture towards employee performance in the Rural Bank industry in Badung Regency.
\end{abstract}

Key-Words: - culture organization, innovative work behavior, employee performance

Received: May 20, 2019. Revised: May 1, 2020. Accepted: May 16, 2020. Published: May 31, 2020

\section{Introduction}

The increasing competition in various economic sectors is triggered by globalization requires industry players to adjust their behavior, methods, and business strategies to be able to maintain business existence and sustainability. Adaptability to respond the changes in the company's internal and external environment is absolutely necessary considering the environment is one of the dominant factors which determines the sustainability and competitive advantage of the company $[1 ;[2]$. Competition that occurs currently without exception is also be perceived by the banking sector business. One of the developing banking sector businesses in Indonesia is the Rural Bank.

Rural Bank business activities are primarily intended to serve small businesses and communities in rural areas. There are 135 Rural Bank in Bali Province spread across nine regencies / cities, and among them, there are 52 Rural Bank operating in Badung Regency which is the region with the hugest economic development.
Compared to the standards (best practices) set by the Financial Services Authority, the performance of Rural Bank in Badung Regency for the past 3 (three) years has shown a fairly good performance. An unfavorable development occurred in the NonPerforming Loan (NPL) indicator, which included bad debt, doubtful and loss loan. Even now, the NPL of Rural Bank in Badung Regency is almost doubled the Financial Services Authority standard.

Employee performance will greatly determine the performance of Rural Bank in Badung Regency. From the evaluation results conducted on Rural Bank employees in Badung Regency, it discovered that the majority of employees are unable to meet the predetermined targets in terms of lending and third party funding, in this case the role of directors becomes more dominant. Therefore, it indicated low quality of employee performance.

Research on employee performance has been carried out by several researchers such as, [3]; [4]; [5]; [6]. [3] conveyed that employees are valuable resources (assets) of the organization. 
Organizational success or failure really depends on employee performance. Therefore, organizations invest large amounts of funds on employee development. Whereas, [4] emphasized that individuals working in business segments are motivated by autonomy, freedom and responsibility which given in carrying out their duties according to the determined position. While, [5] discovered that if top management puts their focus on employee motivation, it will positively enhance employee performance. Furthermore, [6] stated that companies with trained employees have more positive impact on the employee performance.

Employee performance in a company could be influenced by several factors; one of them is organizational culture. As an organization, especially those engaged in merit / services such as banking, honest and specialized human resources with particular skills and abilities are greatly required. Furthermore, this industry also demands work culture which is reflected from prevailing culture in the company or also called organizational culture. It has imperative role in lifting up organizational performance including employee performance. Organizational culture is conceptualized as shared beliefs and values within organizations that contribute to form employee behavior patterns [7]. [8] defined organizational culture as an impetus that acknowledge the efforts and contributions of organizational members and provides holistic comprehension of what and how to achieve it, how goals are interrelated, and how each employee can achieve goals. In addition, [9] summarized organizational culture as a collective process of thought that distinguishes one group member from another group. Thus, the concepts above emphasized that organizational culture could be a room to keep the employees in line with organizational goals.

Innovative work behavior reflects the ability of individuals to adapt effectively to their work by modifying themselves or the work environment through innovation [10]. Many studies have found that being creative at work prone to allow employees to improve their personal performance [11]; [12]. Some researchers showed that innovative work behavior has a positive effect on individual performance. Based on the research conducted by [13] revealed that innovative work behavior is positively related to task performance. Whereas, [14] in his findings explained how innovative behavior of teachers could enhance teachers performance to be more productive. Similarly research conducted by [15], empirical evidence found that behavior innovative and loyal attitudes have a positive impact on the lectures performance. Strong innovative behavior has a positive effect on career satisfaction with lecturer performance as an intervening variable. Furthermore, loyal attitude is also shown a positive effect on career satisfaction with lecturer performance as an intervening variable. Therefore, lecture performance is proven in bridging the gap.

Based on empirical research, business issues, and research gaps relating to innovative work behavior, organizational culture and employee performance, it is necessary to conduct further research on the influence of organizational culture on employee performance mediated by innovative work behavior in the Rural Bank industry in Badung Regency, Bali province.

The purpose of this study are to explain: (1) the influence of organizational culture on innovative work behavior; (2) the influence of organizational culture and innovative work behavior on employee performance; and (3) the role of innovative work behavior in mediating the influence of organizational culture towards employee performance in the Rural Bank industry in Badung Regency, Bali Province.

\section{Literature Review}

\subsection{Organizational Culture}

In general, every company has an organizational culture that is values and trust in order to foster a set of management practices to overcome the problems of internal integration and external adaptation to the company, where the activities carried out come from the dominant existed values in the organization. The definition proposed by [16], emphasized that organizational culture is the norms and values that direct the behavior of organizational members. Each member will behave in accordance with the prevailing culture in order to be accepted by the environment. The theory proposed by [17] that organizational culture can be found in 3 (three) levels, namely assumption level, values, and artifacts.

[18] argued that "organizational culture is a set of assumptions or systems of beliefs, values and norms developed in organizations that serve as guidelines for the behavior of its members to overcome the problem of external adaptation and internal integration". [9] defined culture as the collective programming of the members of one group or category of people from another. The definition of mind in that concept is head, heart, and hands, namely thinking, feeling, and acting, with consequences against beliefs, attitudes, and skills. Culture involves values, where value system is the core of culture values will include the overall 
concept of symbols, heroes, and rituals [9].

The organizational culture according to [9] included five dimensions, namely:

1) Affectivity (need for rewards) versus affective neutrality (survive).

2) Self-orientation vs. collectivity orientation.

3) Universalism (applying general standards) versus particularism (taking relationships specifically for certain cases or conditions).

4) Ascriptions (judging them for what they are) versus achievement (judging others according to what they do).

5) Specificity (limiting relationships with others in special circumstances) versus diffusiveness (unpriority restrictions in natural relationships).

The cultural model of [19] presented the interrelationships between organizational culture, management practices, performance and effectiveness. This model explained the importance of the relationship of management practices with basic assumptions and beliefs in assessing the effectiveness of organizational culture. [19] divided the organizational culture dimensions based on four main culture traits, namely: (1) adaptability; (2) mission; (3) involvement; (4) consistency. Hofstede and Schein's theory of elements and level of organizational culture could be collaborated with theory of [19], that in essence, the model of organizational culture developed from time to time has a relationship with one another, which includes beliefs, values, and norms which recognized by the company, then realized in the form of a goals, vision, mission, and strategies that are believed to be achieved. The realization of the statement must be achieved through a real process practiced in the company. Organizational culture has elements that can influence the perfection of organizational culture formation. The elements of organizational culture proposed by[9] include: (1) professionalism; (2) leadership; (3) trust in colleagues; (4) regularity; (5) conflict; (6) integration

\subsection{Organizational Culture Inventory (OCI)}

The emergence of culture as a relevant concept to the organization and its effectiveness has resulted in many unresolved issues regarding organizational design, development, and organizational study. Unanswered questions about the meaning and content of culture [20]; methods that must be measured [17] and, more fundamental, the cultural feasibility of and direction to be taken. While the debate around these issues continues, culture has been accepted as a fact of organizational life by managers and has become an integral aspect of many organizational change programs.

The concept of organizational culture stems from research in organizational behavior field which characterized by qualitative methods utilization. For some uses, this method comes from issues of interest to scientists who have studied in organization culture: symbolism, sense formulation, and socialization [20]. Involving unique individual perspectives who strongly agree with qualitative research. However one the strongest strategy for organizational development is data-based change an approach that generally depends on the use of quantitative measures [21].

Qualitative and quantitative methods are complementary approaches for organizational processes and attributes study and assessment. Although both methods potential to produce a collection of cumulative information for assessment and testing of theories, a quantitative approach may be more practical for the purpose of analyzing databased changes in organizations. The method described here is a quantitative approach to the assessment of specific aspects of organizational culture, namely shared norms and expectations that guide members' thoughts and behavior. The measurement instrument in question is the Organizational Culture Inventory [22], designed to be used in intra-and inter-organizational comparisons in research and to promote cultural change through organizational development programs guided by surveys.

Organizational Culture Inventory (OCI) is an instrument designed to evaluate organizational culture in terms of norms of behavior and expectations related to shared beliefs and values of members of the organization [22]. OCI measures what individuals and groups within the company as expected of them and will be strengthened and valued. It also allows organizational members to consider a culture that for them would be ideal to maximize business performance, and what kind of behavior is expected of them in that ideal culture. Therefore, the difference between the current and ideal organizational culture of an organization can be measured by OCI. There are 12 sets of normative beliefs and expectations of shared behavior referring to 12 different cultural styles placed around the complex, with their proximity reflecting the expected level of association. The 12 intended cultural styles are: (1) achievements; (2) selfactualization; (3) humanistic encouragement; (4) affiliates; (5) approval; (6) conventional; (7) depends; (8) avoidance; (9) opposition; (10) power; (11) competitive; (12) perfectionist.

\subsection{Innovative Work Behaviour (IWB)}

Innovation is seen as the creation and implementation of 'new combinations'. The term new combination can refer to products, services, work processes, markets, policies and new systems. In innovation, additional value can be created, both for organizations, shareholders, and wider 
community. Therefore, themost definitions of innovation include the development and implementation of something new [23].However, the term 'new' explained by [24] does not mean originality but more refer to newness (novelty). The meaning of the novelty is made clear by Schumpeter's opinion that innovation is creating and implementing something into one combination. With innovation, people can improve the value of products, services, work processes, marketing, delivery systems, and policies, not only for the company but also for stakeholders and society [23].

'Novelty' is also related to the dimensions of space and time. 'Novelty' is tied to the dimensions of space, means that a product or service will be seen as something new in one place but not new in another place. However, this distance dimension has been bridged by the progress of information technology which is so powerful and could narrowed the distance. When a new invention is introduced to a particular society, in short time ,the world will know this breakthrough.

Therefore, this 'novelty' is relatively more universal. Novelty is related to dimension of time. Based on Indonesian history, Borobudur and the making process of keris and batik are concluded as innovation in that era. The scope of innovation in organizations[25], starts from development and implementation of new ideas that have an impact on theory, practice, or lower scale and the improvement of daily work processes and work designs. If viewed from rapidity on inovation process, there are two kinds of innovations such as radical and incremental innovation [26]. Radical innovation is carried out on a large scale,specialized experts and usually managed by the research and development department. This radical innovation is often done in manufacturing and financial service institutions. Whereas incremental innovation is a process of adjustment and implementation of small-scale improvement. Those who make this innovation are all parties involved so that the empowerment approach is in accordance with this incremental innovation model [27].

The concept of 'Innovative Work Behavior' (IWB) is increasingly popular in the scientific literature. Economists define innovation as a major determinant of the competitiveness of companies hence social scientists and psychologists discuss how organizational innovation could be promoted. Employees are important drivers for organizational innovation. They have knowledge capital which is substantial for the development of innovation. It takes a new combination from existing habit, process and products. Central human resource challenge is to create an environment that stimulates employees to enable their innovative potential. Literatures about the concept of 'High Performance
Work Systems 'or' social innovation 'illustrates the importance of employee-based and practice-based innovation for organizational survival [28].

The founding fathers of the IWB concept, [28], did not define IWB. They only describe the behavior associated with the IWB and point to several surrounded dimensions. The authors, who provide definitions for IWB, mostly refer to general definition of innovation as proposed by [29]. The IWB dimension is divided into four types, including: (1) opportunity exploration, the emergence of an issue or riddle that need to be resolved. The trigger can be an opportunity to improve conditions or it can be a threat that requires immediate response; (2). The idea generation, is the next element of the IWB and forms the first step in exploiting opportunities.

\subsection{Employee Performance}

Etymologically, term of performance comes from word work achievement, as stated by [30]. He defined performance or work achievement as desired result of behavior. [31] revealed that work performance is a personal ability to achieve better achievement and organizational objectives. Whereas, [18] defined performance as a successful achievement of employee in undertaking their duties within a specific period of time.

The description of performance involves 3 (three) substantial components, including: objectives, size, and assessment. Determining the objectives of each organizational unit is a strategy to enhance work performance. This goal will give direction and influence expected behavior of the organization work for everyone. However, setting goals solely is not enough because it requires a measure of whether someone has achieved the expected performance. For quantitative and qualitative, performance standards for each task and position play important role. The third aspect of performance definition is assessment. Regular performance assessment that is associated with the process of achieving each person's performance goals.

This action will make people always oriented towards goals and work behavior accordance with the goals. Therefore, it is clear that the notion of performance with purpose, size, operational, and regular assessment has an important role in nurturing and lifting up people's motivation. An accurate identification of influence factors of work performance is a fundamental pathway for rigorous supervision and effective decision making in the process of strategy setting. Furthermore, the leader should understand about causality attribute that underline individual performance.

[30] stated that employee performance is the result achieved goals by people in relation to their 
position in the organization. According to [32], achievement or performance includes an organization's business objectives. For lower level managers, performance is a goal that helps people in achieving the overall mission. For each organizational unit the task of management is to achieve performance as measured by relevant criteria. For business companies, economic performance is measured by the value of sales, market share, profits, return of investment and assets growths. In line with Gibson's view of [32], they also indicated that the performance of each manager and unit is very much determined by the status of the organization, scope of duties and authority.

To know the factors that influence the performance of employee, a review of several performance theories is required to be carried out. Theoretically there are three groups of variables that affect work behavior and performance, such as: individual, organizational variables and psychological variables. The three groups of variables affect work behavior which ultimately influence person / employee performance. Related behavior to performance linked to tasks must be completed to achieve the goals of position and task. [33] revealed several factors used to measure employee performance, namely: (1) The quality level of work results; (2) Tenacity and durability of work; (3) discipline and attendance level; (4) The level of cooperation between co-workers; (5) work safety concern; (6) work result responsibility; (7) initiative / creativity level

\subsection{Previous Research Result}

Research about positive influence of organizational culture against employee performance was conducted by [34];[35];[36];[37]; [38];[39];[40];[41]. Furthermore there were several studies that also showed the positive influence of organizational culture on innovative work behavior such as: [43]. Results of previous studies from: [14]; [15], revealed that innovative work behavior has a positive and significant impact on employee performance. Innovative work behavior also mediates the influence of organizational culture on employee performance, as well as research from: [44];[45]; and [13].

\section{Research Methodology}

The population of this study was the Rural Banks employees of Bali Province in the non Sarbagita area, which numbered 537 spread across 35 Rural Banks. Sampling is based on the Slovin formula with a precision level of $9 \%$, so the sample size is 100 employees. The method of determining the number of respondents in each Rural Banks is carried out in proportional random sampling.
Data analysis was carried out with the SmartPLS 3.0 program which consisted of 3 stages, namely: measurement model evaluation, structural model evaluation, and hypothesis testing. Evaluation of measurement models includes convergent validity and discriminant validity, while structural model evaluations include R-Square $\left(\mathrm{R}^{2}\right)$, Q-Square $\left(\mathrm{Q}^{2}\right)$, and Godness of Fit (GoF).

\section{Results And Discussion}

\subsection{Data Analysis Result}

Data analysis with the SEM-PLS approach consists of two stages including the outer model and inner model examination. The outer model test was conducted to evaluate the first order construct, which was done by testing the validity and reliability of indicators on the construct. The test results indicated that all indicators meet the requirements of model validity and reliability. For more details, Figure 2 displays the outer loading indicator of the construct, and it appears that all indicators are valid considering the loading factor is more than 0.5 .

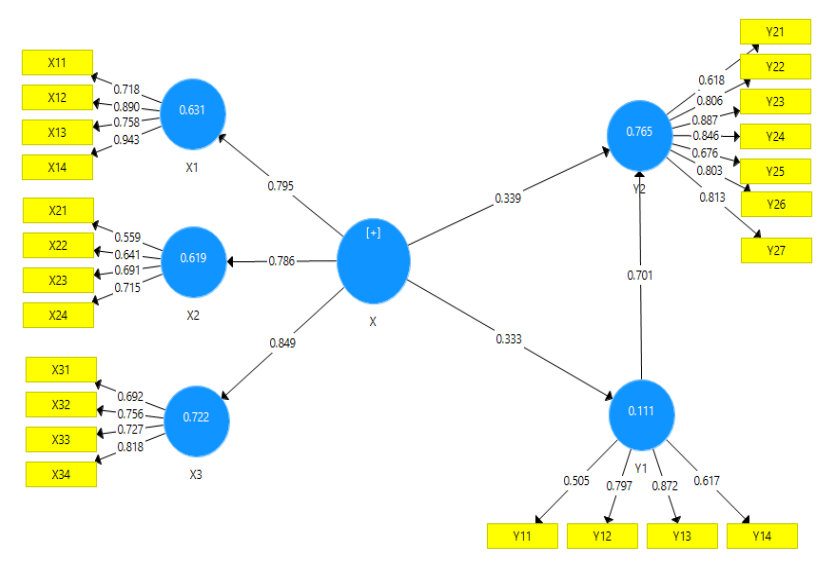

Figure 2: Outer Loading

Note: $\mathrm{X}=$ Culture Organization; $\mathrm{Y}_{1}=$ Innovative Work Behavior; $\mathrm{Y}_{2}=$ Employee Performance; $\mathrm{X}_{1}=$ Constructive Culture; $\mathrm{X} 2=$ PassiveDeffensive Culture; $\mathrm{X}_{3}=$ Aggressive-Deffensive Culture

Because of the model has met the criteria of outer model, so that the inner test model has been second examination to evaluate the R-square and Qsquare values on endogenous variables such as innovative work behavior and employee performance. The R-square and Q-square values are shown in Table 1.

Table 1

R-Square and Q-Square Predictive elevance

\begin{tabular}{lcc}
\hline \multicolumn{1}{c}{ Variables } & $\mathrm{R}$ & $\mathrm{Q}$ \\
& Square & Square \\
\hline Innovative Work Behavior (Y1) & 0.111 & \\
\hline Employee Performance (Y2) & 0.765 & 0.791 \\
\hline Source: Data processed, 2019 & &
\end{tabular}

Based on Table 1, it is be discovered that the Rsquare value is 0.111 which means that $11.1 \%$ 
variation in the value of innovative work behavior could be explained by variations in organizational culture. Similarly, the R-square value of 0.765 explained that $76.5 \%$ of the variation in the value of employee performance is influenced by variations in organizational culture and innovative work behavior. It means that $22.9 \%$ of the variation in value from the business performance of silver handicraft SMEs in Gianyar Regency can be explained by variations in innovation and competitive advantage, while the remaining $77.1 \%$ is elucidated by other factors outside the research model. Whereas, the Q-square value of 0.7911 indicates that the model has high predictive prevalence, hence the model was feasible to predict. Figures of 0.791 can be interpreted by variations in employee performance by 79.1 percent can be explained by variations in organizational culture and innovative work behavior, while the remaining 20.9 percent is influenced by other variables outside the model.

The inner model test is also done by evaluating the path coefficient between the research variables, both directly and indirectly, as presented in Table 2 .

Table 2

Path Coefficient

\begin{tabular}{lccc}
\hline \multicolumn{1}{c}{ Path } & $\begin{array}{c}\text { Original } \\
\text { Sample }\end{array}$ & $\begin{array}{c}\mathrm{T} \\
\text { Statistics }\end{array}$ & $\begin{array}{c}\mathrm{P} \\
\text { Values }\end{array}$ \\
\hline $\mathrm{X} \rightarrow \mathrm{Y}_{1}$ & 0.333 & 4.776 & 0.000 \\
\hline $\mathrm{X} \rightarrow \mathrm{Y}_{2}$ & 0.339 & 7.398 & 0.000 \\
\hline $\mathrm{Y}_{1} \rightarrow \mathrm{Y}_{2}$ & 0.701 & 17.051 & 0.000 \\
\hline $\mathrm{X} \rightarrow \mathrm{Y}_{1} \rightarrow \mathrm{Y}_{2}$ & 0.234 & 4.701 & 0.000 \\
\hline
\end{tabular}

Source: Data processed, 2019

\subsection{Hypothesis Testing Results}

Based on Table 2, hypothesis testing can be done by evaluating the regression coefficient, $t$-value, and $\mathrm{p}$-value in each path. If the regression coefficient shows positive value, the effect will bein positive direction. Furthermore, if the $\mathrm{t}$-value is greater than 1.96 and the p-value is smaller than 0.05 then the effect is declared significant. In accordance with these criteria, the results of the research hypothesis testing are obtained as follows:

$\mathrm{H}_{1}$ accepted: Organizational culture has a positive and significant effect on employee performance.

$\mathrm{H}_{2}$ accepted: Organizational culture has a positive and significant effect on innovative work behavior.

$\mathrm{H}_{3}$ accepted: Innovative work behavior has a positive and significant effect on employee performance.

$\mathrm{H}_{4}$ accepted: Innovative work behavior significantly mediates the influence of organizational culture on employee performance.

\section{Discussion}

\subsection{The influence of organizational culture on} employee performance

The results of hypothesis testing indicated that organizational culture has a positive and significant effect on employee performance. This showed that better application of organizational culture will result in better employee performance. The test results proved that organizational culture reflected through 3 (three) dimensions, namely constructive culture, passive-deffensive culture, and aggressivedeffensive culture with relevant indicators associated with employee performance in Rural Bank in Badung Regency.

Badung proved to have good categories reflected by humanistic encouragement indicator (dimensions of constructive culture), conventional (passivedeffensive culture dimensions) and power (aggressive-defensive culture dimensions) affect employee performance which highly reflected on quality level of work. Improvement quality of employee performance could happen if the company prioritizes their employee participation, supportive, constructive and open to the external influences. In the other hand, supportive characteristics of employee such as work carefully and bureaucratically, adjustable and obedience with the regulation is very helpful to achieve optimal quality of work. In addition, high responsibility, responsive towards their superior demands, the ability to supervise subordinate greatly influences quality level of work. Banking management that is full of trust and risks requires a supportive culture between stakeholder, develop and transparent, prudence priority, responsible are substantially needed in order to avoid public confidence loss and banking risks.

This is consistent with previous research conducted by [46]. The result revealed that constructive organizational culture has a significant effect on employee performance. The existence of a significant influence shows that the better company's treatment on constructive organizational culture will absolutely enhance the employee performance. Passive-defensive organizational culture also has a positive and significant effect on employee performance. It showed that doing work conservatively, corporate bureaucracy, central decision making, and employee involvement in decision making have a positive influence on employee performance. Aggressive-defensive organizational culture is one factor that has a positive and significant effect on employee performance. This emphasized that a critical attitude, argumentation, appropriate use of power, not arbitrary, healthy competition, the assumption of employee competition could escalate employee performance If those indicators are maximized. 
The research conducted by [34] found that corporate culture is imperative in every organization and it showed a positive impact on employee work performance. In addition, the corporate culture affected the level of organizationproductivity in a positive way. Every individual has a different culture and belief and when they joined an organization that has a totally different culture and belief, he must be allowed to internalize himself with the culture and values of the organization to find out whether he can handle it or not. In cases when organizational culture must be changed, employees must be informedinitially, thus it can improve commitment and efficiency of group. Organizational culture must bind all members and staff of the company because this will encourage uniformity among members of the organization and increase group commitment and efficiency.

Other research, namely [36] stated that organizational culture as social glue and behavioral guidelines are urgently needed so that all parties can create maximum performance for the company. Another research conducted by [4] tried to evaluate the overall impact of organizational culture on employee performance. It is indicated that there was a positive relationship between organizational culture and employee performance. A strong culture in the organization leads to increase employee commitment in achieving organizational goals. [35] in their study stated that there was a positive relationship between organizational culture and work performance. It is very important to create a strong organizational culture in order to improve employee work performance by increasing adaptability, mission, involvement, and cultural consistency.

\subsection{The influence of organizational culture on innovative work behavior}

The results of hypothesis testing indicated that organizational culture has a positive and significant influence on innovative work behavior. It showed the innovation of work behavior will increase if better organizational culture is applied.

Based on the results of organizational culture description indicators, Rural Bank in Badung regency have been labelled by good category. It was reflected through humanistic impetus indicators (constructive culture dimensions), conventional (passive-defensive culture dimensions) and power (aggressive-defensive culture dimensions) affect innovative work behavior and it manifested on opportunity exploration. Employees who work in a company that prioritizes the participation of their employees, supportive culture, constructive, and open to influence can easily identify the existed opportunities. Similarly, the employees who work with care, bureaucracy, adjustable and obey the rules are very helpful to identify existed opportunities. In addition, every employee who has high sense of responsibility, responsive, and able to supervise subordination is very influential in finding and identifying various existed opportunities. Banking management that is full of trust, full of risks, and very competitive requires supportive behavior, openness, prudence priority, responsible, critical to change, maintaining competitive culture will be very helpful in finding and identifying every opportunity that exists.

This is consistent with research from [47] stated that the relationship between organizational culture and innovation has been the subject of extensive research over the past few decades. Research revealed that Quinn and Rohrbaugh's competitive value framework provides a meaningful structure for the ideational aspects of organizational culture. The analysis showed that the suitability of various cultures with organizational innovation goals can be described based on the framework. The control theory was used to explain the relationship between organizational culture and innovation. While culture described the ideational aspects of organizational values, clan control explained its coordinative effects. The research hypothesis was that managers of innovative organizations were likely to apply a culture of development, which emphasized external orientation and flexibility. However, a group and rational culture to some extent conform to innovative organizational goals and thus can be an appropriate social control strategy. Hierarchical culture emphasized internal control and orientation and prone not to be found in innovative organizations. Moderator analysis of cultural innovation relationships revealed that it is not influenced by the difference between radical and incremental innovation, and there is only weak evidence for the influence of innovation adoption versus the generation of it. Therefore, managers who follow an innovation (radical) strategy must build a developmentculture in their organization. If innovation only representsa small piece of company's long term goals, rational culture oriented on efficiency and group culture might be a proper option.

Research conducted by [43] identified organizational culture factors related to company innovation, as well as to find out the strength of this effect. The results of the study showed that the number of applied product innovations (new brand and development) and process innovation (brand new and development) increases along with the size of the company.

\subsection{The effect of innovative work behavior on employee performance}

The results of hypothesis testing indicated that 
innovative work behavior has a positive and significant effect on employee performance. It showed that better innovative work behavior in line with improvement of employee performance.

Based on the results of the description of innovative work behavior indicators on Rural Bank in Badung Regency are categorized as good. It reflected through the opportunity exploration indicator, it affects employee performance which is highly reflected in the level of quality of work. Employee behavior is manifested in the ability to find and identify opportunities, which can occur due to incongruence and discontinuity because of incompatibility with expected patterns. The examples of this issue were problem with work, unmeet consumer needs, and trends changing. With the ability of the employee to identify opportunities and then turn these opportunities into something useful for the bank's operations, will absolutely be able to improve the quality of work.

This is consistent with research conducted by [48]. The result stated that it would be helpful to encourage employees to have flexible role orientations if they were urged to show innovative work behavior. That's mean; employees who are willing to take roles from their standard roles are more likely to display innovative work behaviors. The research conducted by [15] was to analyze innovative behavior and loyal attitudes towards career satisfaction with lecturer performance as an intervening variable. The results of this study showed that every innovative behavior and positive loyalty attitude influence the performance of lecturers. The campus environment must provide space to make their lecturers more innovative. Willing to try new things and try something that has never been done before. There might be many new ideas presented by their lecturers through discussions, seminars, workshops, and team work as well as lecturer work experience. However, if the idea is limited to paper notes that have never been followed up, it will hamper lecturer performance and career satisfaction will not be achieved. Research conducted by [14] explored the relationship between work climate, innovation behavior on the performance of primary and secondary school teachers. The findings of this study mention innovation behavior in schools could strengthen teacher performance by shaping teachers' perceptions of the definition of their roles.

\subsection{The role of innovative work behavior mediates the influence of organizational culture on employee performance}

The results of hypothesis testing indicated that innovative work behavior mediates significantly influence the organizational culture on employee performance, which means that the influence of organizational culture on employee performance could be explained only by innovative work behavior. To improve employee performance, organizational culture should be optimized through efforts to improve innovative work behavior, so that it will further increase employee performance.

The findings of this study showed that organizational culture consisting of constructive culture, passive-defensive culture, and aggressivedefensive culture that is reflected by humanistic, conventional, and power impulses will influence the innovative work behavior of employees presented by behavior finding and identifying existed opportunities, and innovative work behavior will be able to improve employee performance reflected by the level of quality of work.

This is consistent with research from [43].This case study was conducted on packaging machine manufacturers and can be used as an example for other companies working in very innovative fields of work. The purpose of this study was to investigate the level of innovative work behavior, the type of organizational culture and the relationship between work behavior innovative and organizational culture. Employees perceive the dominant cultural flow as a market culture and believe that they can improve their innovative work behavior as indicated by higher average scores on preferred innovative work behavior than current innovation level. The preferred organizational culture is family culture. The conclusion of this study was the transition from current market culture towards family culture was more necessary, but in the meantime the market culture must be preserved. By considering the facts that IWB is very important for tourism companies, exploring the contributing factors that influence IWB can be beneficial. Correlation analysis revealed that IWB was found to be significantly correlated with mutual cooperation. Because IWB is very important for improving the performance and success of each organization, the organizational culture must be arranged to encourage employees in terms of IWB. The research conducted by [13] aimed to find out how innovative work behavior of employees influences their task performance and how managers can influence innovative work behavior. The two research models use the questioning approach: (1) the first research model discusses how employee expectations influence innovative work behavior and how innovative work behavior is related to task performance; and (2) the second research model relates to factors that influence the formation of expectations. The first research model investigated the role played by employee expectations in innovative work behavior. This examined the effects of innovative self-efficacy and expected outcomes on innovative work behavior. 


\section{Conclusion}

The results showed that organizational culture had a positive and significant impact on innovative work behavior, as well as organizational culture and innovative work behavior had a positive and significant effect on employee performance in the Rural Bank industry in Badung Regency. In addition, it can be concluded also that innovative work behavior mediates significantly the influence of organizational culture on employee performance in the Rural Bank industry in Badung Regency.

Rural Bank leaders or managers in Badung Regency in particular, need to be aware of several things in order to succeed in business activities in the midst of intense competition today. It required applying an aggressive culture that is power oriented, because with the authority given to employees they will responsible and willing to control subordination and at the same time, be responsive to the demands.

For Rural Bank management, it is suggested to maintain the innovation of employee behavior particularly related to finding opportunities, such as the emergence of problems in work patterns, the existence of unmet consumer needs, or an indication of changing trends. Hence, the level of high quality work will be achieved. In this case could be seen from the results of the performance carried out by employees such as the quality of work, timeliness and targets set by the company. Further research needs to develop this research with qualitative studies to be able to explore more profound issues related to the influence of organizational culture on innovative work behavior and employee performance.

\section{References:}

[1] Porter, M.M. (1979). How Competitive Forces Shape Strategy. Harvard Business Review. (MarchApril). pp.1-10.

[2] Mohant, J. \& Rath, B.P. (2012). Can Organiational Culture be a Predictor of Organizational Citizenship Behaviors? International Journal of Innovation, Management and Technology, Vol. 3, No. 1.

[3] Hammed, Waheed. 2011. Employee development and Its affect on Employee Performance A Conceptual framework. International Journal of Business and Social Science. Vol. 2. No. 13.

[4] Shahzadi, I., Javed, A., Pirzada, S.S., Nasreen, S., Khanam, F. 2014. Impact of Employee Motivation on Employee Performance. European Journal of Business and Management, Vol.6, No.23, 159-164.

[5] Zameer, H., Ali, S., Nisar, W., Amir, M. 2014. The Impact of the Motivation on the Employee's Performance in Beverage Industry of Pakistan.International Journal of Academic Research in Accounting, Finance, and Management Sciences, Vol. 4, No. 1, 293-298
[6] Iqbal, N., Anwar, S., Halder, N. 2015.Effect of Leadership Style on Employee Performance.Arabian Journal of Business and Management Review, Vol.5, Issue 5, 1-6.

[7] Kotter, J.P., Hesket, J.L. 1992. Corporate Culture and Performance. New York: Free Press.

[8] Gordon, G., Cummins, W. 1979. Managing Management Climate. Toronto. Canada: Lexington Books.

[9] Hofstede, G. (1994). Cultures And Organizations. New York: Mcgraw-Hill.

[10] Janssen, O., van de Vliert, E., and West, M.A. 2004. The Bright and Dark Sides of Individual and Group Innovation: A Special Issue Introduction, Journal of Organizational Behavior, No. 25, pp. 129-145.

[11] Gilson, L.L. 2008. Why Be Creative: A Review of the Practical Outcomes Associated with Creativity at the Individual, Group, and Organizational Levels. In Zhou, J., and Shalley, C.E. (Eds.): Handbook of Organizational Creativity, pp.303-322, New York: Lawrence Erlbaum Associates.

[12] Gong, Y., Huang, J.-C., and Farh, J.-L. 2009 Employee Learning Orientation,Transformational Leadership, and Employee Creativity: The Mediating Role of Employee Creative self-Efficacy, Academy of Management Journal, Vol. 52, No. 4, pp.765-778.

[13] Dörner, N. (2012). Innovative Work Behavior: The Roles of Employee Expectations and Effects on Job Performance. Dissertation. University of St.Gallen

[14] Balkar, B. (2015). The Relationship Betwen Organizational Climate, Innovative Behavior and Job Performance of Teacher. International online Journal of Educational Sciences, Vol. 7, No. 2, pp. 81-92.

[15] Winarti, E.H.S.\& Suharnomo. (2015). Analysis of innovative behavior and loyal attitude toward carrer satisfaction with the performance of lectures as intervening variables (empirical studies on the Kopertis Region VI in Indonesia. American International Journal of Contemporary Research, vol.5, No.2; April 2015.

[16] Luthans, F.(1998).Organizational Behaviour. Eight Edition.New York: Mc.Graw.

[17] Schein, E. (1985). Organizational culture and leadership. San Fransisco: Jossey-Bass.

[18] Mangkunegara, A. P. (2005). Sumber Daya Manusia Perusahaan. Bandung: Remaja Rosdakarya.

[19] Denison. (1990). Cooporate Culture And Organizational Effectiveness. New York: Willey.

[20] Martin, J.\&Siehl, C. (1983). Organizational Culture and Counterculture: An Uneas Symbiosis. Organizational Dynamic, 12 (2) Autumn, 52-64.

[21] Huse, E.F.\&Cummings, T.G.(1985). Organizational Development and Change. 3rd Ed. USA: West Publishing Co.

[22] Cooke, R.A.\& Lafferty, J.C. (1983). Leve1 V:Organizational Culture Inventory (Form 1). Plymouth, MI: Human Synergistics.

[23] De Jong, J. \&Hartog, D.D. (2003). Leadership as a determinant of innovative behavior, A Conceptual framework. http://www.eim.net/pdf-ez/H200303.pdf

[24] Adair, J. (1996). Effective Innovation.How to Stay Ahead of the Competition. London: Pan Books. 
[25] Janssen, O. (2003). Innovative Behaviour and Job Involvement at the Price Conflict and Less Satisfactory Relations with Co-workers. Journal of Occupational and Organizational Psychology. Vol. 76, pp. 347 - 364.

[25] Scott, S. G., Bruce, R. A. 1994. Determinants of Innovative behavior: A Path Model Of Individual Innovation in the Workplace. Academy of Management Journal. Vol. 37, No. 3, pp. 580-607

[27] Jones, C.P.(2004). Investment. New York: PrenticeHall.

[28] Pot, Frank, and Vaas, F. (2008). Social Innovation, the New Challenge for Europe. International Journal of Productivity and Performance Management, Vol. 57, No. 6 (July 25), pp. 468-473. doi:10.1108/17410400810893400.

[29] West, M.A.\& Farr, J.L. (1990). Innovation and Creativity at Work. Oxford, England: John Wiley \& Sons Ltd.

[30] Gibson, L. James., M. J. I., \&Donnely, H. J. (1997). Organisasi dan Manajemen, Perilaku Struktur Proses. Jilid 1. Edisi Kelima. Terjemahan. Jakarta: Erlangga.

[31] Hasibuan. M. (2003). Organisasi dan Motivasi. Jakarta: Bumi Aksara

[32] Kast, F. E., \&Rosenzweig, J. E. (2007). Organisasi dan Manajemen. Jakarta : PT. Bumi Aksara.

[33] McNeese, S.D. (1996). Increasing Employee Productivity, Job Satisfaction And Organizational Commitment. Hospital \& Health Services Administration. Vol.41 No.2, Summer, pp.160-175.

[34] Ojo, O. (2009). Impact Assessment Of Corporate Culture On Employee Job Performance. Business Intelligence Journal. August 2009. Vol. 2, No. 2.

[35] Menaka, W. H. S. \& Chandrika, K. A. C. (2017). Impact of Organizational Culture on Employee Job Performance in a Large Scale Apparel Company (BASL-Finishing). In Proceedings of International HR Conference, 2(1): 65-74.

[36] Koesmono, T.H. (2011). Pengaruh Budaya Organisasi Dan Kepemimpinan Terhadap Kinerja Melalui Variabel Mediasi Komitmen Organisasional Karyawan Perusahaan Swasta Di Surabaya Timur. Jurnal Mitra Ekonomi dan Manajemen Bisnis. Vol. 2, No. 2, Oktober 2011, pp.155-171.

[37] Uddin,M.J., Luva, R.H., Hossian, S.M.M. (2013). Impact of Organizational Culture on Employee Performance and Productivity: A Case Study of Telecommunication Sector in Bangladesh. International Journal of Business and Management; Vol. 8, No. 2.

[38] Nyameh, J. (2013). Application of the Maslow's Hierarchy of Need Theory; Impacts and Implications on Organizational Culture, Human Resource, and Employee's Performance. International Journal of Business and Management Invention, Vol. 2 (3), 3945.

[39] Magee, K.C. (2002). The Impact of Organizational Culture on The Implementation of Performance Management. A Dissertation Submitted in Partial Fulfillment of the Requirements for the Degree of Doctor of Philosophy in the Andrew Young School of Policy Studies of Georgia State University.

[40] Sackmann, S. (1991). Cultural Knowledge in
Organization Exploring the Collective Mind. Newbury Park, Cs.: Sage Publication.

[41] Maina, J. (2016). Influence of Organizational Culture on Performance of Commercial Bank in Kenya. A Research Project Submitted in Partial Requirements for the Award of The Degree of Master of Business Administration, School of Business, University of Nairobi.

[42] Jan, M.A., Shah, S.M.A., \&Khan, K.U. (2014). The Impact of Culture on Innovation: The Moderating Role of Human Capital. International Journal of Accounting and Financial Reporting. Vol. 4, No. 2

[43] Rudzewicz, A.S. (2014). Determinants of organizational culture that influence innovation. The Case of Production Companies in Poland. University of Warmia and Mazury in Olsztyn, Poland, The Faculty of Economics.

[44] Stoffers, J., Neessen, P., Dorp, P.V. (2015). Organizational Culture and Innovative Work Behavior: A Case Study of a Manufacturer of Packaging Machines. American Journal of Industrial and Business Management, Vol. 5, pp.198-207

[45] Eskiler, E., Ekici, S., Soyer, F., \&Sari, I. (2016). The Relationship between Organizational Culture and Innovative Work Behavior for Sports Services in Tourism Enterprises. Physical culture and sport. Studies and research. Volume LXIX

[46] Muhammad, E.Z.G \& Mukzam, M.D. (2017). The Effect of Organizational Culture to the Employee Performance. Jurnal Administrasi Bisnis (JAB), Vol. 53, No. 1.

[47] Büschgens, T., Bausch, A., Balkin, D.B. (2013). Organizational Culture and Innovation: A MetaAnalytic Review. Product Development \& Management Association, Vol. 30, No.4

[48] Kessel, M., Weber, H.H., \& Kratzer, J. (2012). Innovative Work Behavior in Healthcare: The Benefit of Operational Guidelines in the Treatment of Rare Diseases. Health Policy. 105(2-3), pp.146153.

\section{Creative Commons Attribution License 4.0 (Attribution 4.0 International , CC BY 4.0)}

This article is published under the terms of the Creative Commons Attribution License 4.0 https://creativecommons.org/licenses/by/4.0/deed.en_U $\underline{S}$ 